\title{
The Best Practice of Vocational Education Development in Developed Country: Reference Framework for Developing Vocational Education in Indonesia
}

\author{
Edy Sulistiyo \\ Electrical Engineering Department, Engineering Faculty \\ Universitas Negeri Surabaya \\ Surabaya, Indonesia \\ edysulistiyo@unesa.ac.id
}

\author{
Djoko Kustono \\ Postgraduate Program \\ Universitas Negeri Malang \\ Malang, Indonesia
}

\begin{abstract}
Efforts to be made in the development of Vocational Education in Indonesia include creating a roadmap for SMK development and refining and aligning the SMK curriculum with competencies according to the needs of the graduates (link and match) to increase the relevance of vocational education not yet in accordance with the needs of the world of work. Best practice analysis is needed to guide the framework of the development of vocational education in the countries of Asean, Germany and South Korea in comparison with the conditions of vocational education in Indonesia. The results of the analysis showed the importance of in-depth study in order to increase the interest in studying in vocational education, better implementation of KKNI (Indonesian National Qualification Framework), introduction of apprenticeship system by adapting vocational education in Germany, vocational education teachers' qualifications adapting the vocational education teacher recruitment system in Germany, the internationalization of vocational education and training aims to provide students with the necessary knowledge, skills and competencies in the international labor market and multicultural society, efforts to increase the number of SMK graduates adapting vocational education in South Korea in which graduates working in the business world at least 3 years period can continue to college without having to take college entrance exams, and efforts to minimize the problem of 'skill mismatch' required mechanisms linking curriculum education in the school with the expected competence of the business world / industrial world so that the type of work competence required for a particular job in accordance with the education taken.
\end{abstract}

Keywords-vocational education, Indonesian National Qualification Framework, internship, teacher qualification, mismatch skills

\section{INTRODUCTION}

Apprentices' performance after vocational educational training (VET) is commonly attributed to the effectiveness of the training. This implies the assumption that learners' development of vocational knowledge and ability is significantly affected by vocational instruction [18].

In the National Education System Act no. 20 of 2003 article 15 described that SMK is a form of secondary education unit that prepares students primarily to work in a particular field [16]. The meaning of vocational education is more specifically described in government regulation (PP) no. 29 in 1990, ie education at the middle level prioritizing the development of students' ability to perform certain types of work [17]. Vocational education has different characteristics from general education, whether viewed from the criteria of education, lessons content, and graduates. The criteria of vocational education system according to [4] among others; (1) education and training orientation; (2) justification of existence and legitimacy; (3) the focus on curriculum content; (4) learning success criteria; (5) sensitivity to community development; and (6) cooperative relations with the community. The theme of educational development referring to the National Long Term Development Plan (RPJPN) for 2005-2025 which is shown in Fig. 1.

The first period in RPPNJP, the development of education is focused on increasing the capacity of education units as education providers in expanding services and improving the modernization of the learning process. The second period, the government encourages to strengthen the services so that education can be perceived by all levels of society. The third period, the development of education is planned as a stage of education that prepares Indonesians to have regional competitiveness. The practice of implementing SMK [10] in Indonesia is now showing the following weaknesses: to organize a single function, ie to prepare students for work, to become employees, and to be less prepared to become entrepreneurs, less responsive to the demands of economic development, weakness of their alignment with the world of work, and there is no guarantee to get a decent job. In order for SMK to play a more important role in economic development, SMK should extend its function from a single function to a Model Vocational School that performs a compound function aligned with the pluralistic needs of society.

The key issues raised are how should efforts be made in order to develop vocational education in Indonesia in accordance with the frame of mind of the development of vocational education in the countries of Asean, Germany and South Korea? The purpose of the best practice analysis of vocational education development is to know the efforts to 
be done in order to develop vocational education in Indonesia in accordance with the framework of the development of vocational education in the countries of Asean, Germany and South Korea.

\section{METHOD}

The method used in the writing of this paper is a review of the literature by making critical analysis of research results related to the development of vocational education in Indonesia. The literature review used is a reference framework of the development of vocational education in the Asean, Germany and South Korea countries compared to the existing vocational education conditions in Indonesia. Literature review is done by giving a relationship between one research with other research related to point of interest, identifying with interpreting and looking for gap / gap. In addition, literature review is also done by searching for similarities (contrast), providing views (criticize), comparing (synthesize), and summarize.

\section{RESUlT AND DiscUSSION}

\section{A. A Comparative Study of Vocational Education in ASEAN Countries}

The analysis results of various educational issues [11] in the Asean countries plus the countries of Australia, China, India, Japan, New Zealand and the Republic of Korea highlight the key issues, challenges and opportunities in improving system performance and reducing educational disparities into three policy areas; 1) policy and management framework, 2) secondary education, and 3) vocational education, which is very important in formulating and operating the reform agenda of education in the ASEAN countries. The comparative review of education in Asean + currently shows; (a) the structure of the educational system varies, generally using $6+3+3$, or using the $6+4+2$ system, (b) the Asean + state uses decentralization at some functions and is accountable to a lesser but centralized level, with teacher management and regulatory standards, (c) the trend of participation rate of Vocational Education in Asean countries tends to decline over the past decade and recognizes the importance of vocational education and nationally incorporated it in economic development plans, but vocational education is considered "unpopular" and the difference between general education and vocational is considered increasingly blurred, and (d) there are variations in countries that prepare labor and educate through vocational education but most have placed a quality assurance system for vocational education and a qualification framework. Various levels of development of ASEAN countries are needed to strengthen the skills and training system to benefit from integration and emerging opportunities as competitiveness including introducing skills certification, portability, and recognition issues [8].

The policy framework that supports the vocational education system in Asean + is the qualification framework for vocational education, but the lack of a national qualification framework does not necessarily signify weaknesses. Some countries including Japan and the Republic of Korea have achieved economic development supported by the development of vocational education without a qualification framework. The 2011-2016 Philippines development plan includes strategies to improve the effectiveness of critical skills demand and high professional level through industries with academic links, labor market information socialization, and career counseling [14].

TABLE I. MINISTRIES RESPONSIBLE FOR VOCATIONAL EDUCATION

\begin{tabular}{|l|l|}
\hline Country & \multicolumn{1}{|c|}{ The ministry responsible for the provision of TVET } \\
\hline Australia & $\begin{array}{l}\text { Department of Education, Employment and Workplace } \\
\text { Relations (DEEWR) }\end{array}$ \\
\hline \multirow{3}{*}{ Indonesia } & $\begin{array}{l}\text { Ministry of Education and Culture, Directorate of SMK, } \\
\text { Ministry of Manpower and Transmigration, Directorate } \\
\text { General of Production Training and Development }\end{array}$ \\
\hline Jepang & $\begin{array}{l}\text { Ministry of Health, Labor and Welfare (MHLW), Ministry of } \\
\text { Education, Culture, Sports, Science and Technology (MEXT) }\end{array}$ \\
\hline Malaysia & $\begin{array}{l}\text { Department of Education (MOE), responsible for vocational } \\
\text { secondary education. Department of Higher Education } \\
\text { (Mohe): responsible primarily for universities, polytechnics } \\
\text { and colleges (TVET). Human resources department; } \\
\text { Department of Entrepreneurship; Department of Science and } \\
\text { Technology; Ministry of Women, Family and Community } \\
\text { Development and others: responsible for skills training in } \\
\text { specific areas in both formal and non-formal learning } \\
\text { arrangements. }\end{array}$ \\
\hline $\begin{array}{l}\text { Republik } \\
\text { Korea }\end{array}$ & $\begin{array}{l}\text { Ministry of Education, Science and Technology (MEST), } \\
\text { Ministry of Works and Labor (Moel). }\end{array}$ \\
\hline Singapura & Ministry of Education (MOE), Ministry of Manpower (MOM) \\
\hline
\end{tabular}

\section{B. Vocational Education in Germany}

Länder is responsible for education and culture ('cultural sovereignty' of Länder). In vocational education and training (VET), the Federal Government is responsible for vocational training in companies, while Länder is responsible for vocational training in schools and vocational schools [12]. Länder is responsible for public sector education, and vocational schools that are under the responsibility of local authorities. All laws concerning schools, including vocational schools, are Land (territory) laws. The Federal Government is responsible in the company, VET non-school. The Federal Department of Education and Research (BMBF) is responsible for centralized Vocational Education and Training coordination, responsibility for fundamental issues in VET policies.

The dual system is implemented at the upper secondary level. After completing the double-system training, the majority of participants took up employment as skilled workers. Most of them took advantage of the opportunity to resume vocational training. Under certain circumstances, eligible students may obtain the academic standards required to enter Fachhochschule in one year at full-time school, and proceed to a higher level of education. Participants who successfully continue vocational training are allowed to study in college. Full-time vocational schools have the highest number of students. These schools prepare for vocational work or training in dual systems. The presence of a full-time vocational school is conducted in the first year of training in a dual system. The right to study at a college or Fachhochschule can be obtained in some educational programs in a full-time vocational school. 


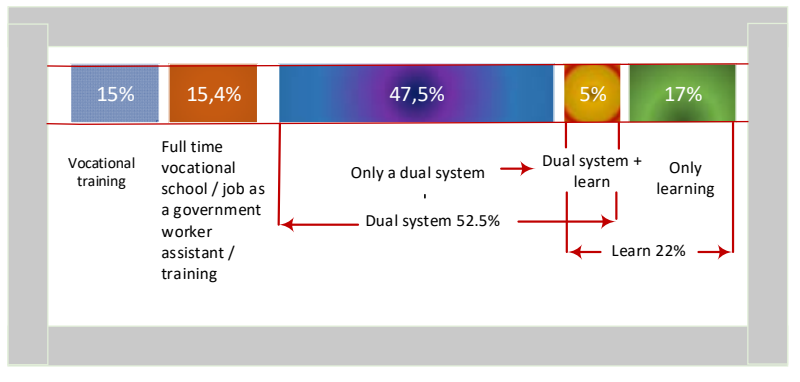

Fig. 1. Cohort structure by type of qualification

Figure 1. Shows the importance of multiple-system training in Germany consisting of various training programs showing the training status achieved by one group. The purpose of multiple system training is to provide programs that instruct basic broad-based vocational training and the qualifications and competencies required by skilled workers in the world of work. In a dual system, a vocational school is an autonomous place of learning and its job is to provide basic and specialized vocational training previously obtained by general education. Vocational schools must provide at least 12 hours of teaching a week, usually eight hours devoted to vocational subjects and four hours for general subjects such as German, IPS/ business studies, religious education and sports.

The main objective of the training is to obtain comprehensive vocational competencies that are designed to fulfill the tasks of employees efficiently, effectively and innovatively, independently, responsibly and cooperatively. Vocational competencies are based on material, social, and methodological competencies.

Assessment of the last exercise is directed to vocational practice, that is, with the requirements of work and processing activities. In Germany, the financing of vocational training and ongoing training is based on a system of financing from various supporters, both public and private. Among them include the Federal Ministry of Education and Research (BMBF), the Federal Ministry of Economy (BMWi), the Federal Agency for Employment (BA), the Ministry of Employment, Economics, Education or Cultural Affairs, the European Union, local governments, companies, unions, Chambers, private institutions, and the individuals themselves.

\section{Vocational Education and Training in South Korea}

The education system in South Korea consists of four levels: Primary, Secondary, High School and Higher Education. The four levels of education are in line with "grades" 1-6 (SD), grade 7-9 (SLTP), 10-12 (SLTA), and grade 13-16 (higher education / S1 program) and post- S3). For senior high school, it is divided into two: public and vocational schools [7]. In South Korea, there are five main subjects: math, science, Korean, social studies, and English. Vocational education in Korea starts in high school. High school graduates can choose public high school or vocational high school. The key features of the vocational education system in South Korea include; 1) education is a high priority in South Korean society, 2) vocational education and vocational training are not integrated, 3 ) the government is committed to strengthening vocational education and training; (Meister High School) Meister High School (MHS), National Competency Standards (NCS), and
Work-learning dual system, 4) non-systematic job training provided by vocational education, and 5) lack of standards to control the quality of job training.

Some policies, such as the Meister High School (MHS) and the policy of "first job, college later", are typical models of vocational education. The main advantages of this model are defined as follows; (a) curriculum to adapt to industry demand, and (b) establishment of school links with the world of work. To address the policy of "main job, high school later", the steps taken are; (1) increasing the number of special high school students, and (2) promoting a system that encourages students who go on to college with certain work experience. High school education system is divided into 5 main programs; agriculture industry, manufacturing industry, IT business, marine / fishery, and vocational household economics. The special high school is described as; (a) secondary level vocational education, (b) to produce qualified technical workforce, and (c) to strengthen student specialization in large industries; agriculture industry, manufacturing industry, IT business, and marine / fisheries.

Policy to revitalize SMA for Special, students are encouraged to get first job and continue their study in the future with some policies as follows; 1) increase the number of vocational graduates, graduates must work in the business world / industry world for at least 3 years then they can continue to college without having to take college entrance exams, 2) admit special high school graduates in continuing to university company there must be departmental program contract, the industry commissioned open education, open universities, credit systems, and universities using open learning, 3) increasing high school graduate scholarships to universities.

Special schools that provide high-quality vocational education selected by the government as Meister High School (MHS) have important features; (a) The school curriculum is tailored to industry needs based on agreements with specific industries, (b) Graduates from MHS are prioritized for employment, while graduates from specialized schools can make a choice between lectures or getting a job. Vocational colleges are encouraged to participate in providing opportunities for work-related courses including; (a) provide a flexible curriculum such as evening lectures and weekend lectures, and (b) provide online classes. The direction of vocational education policy in South Korea, among others; 1) change of government-led system into an industry-led system, 2) strengthening the role of industry by involving sector and company councils; 3) quality management of regulatory training programs; and 4) coordinate the level and content of the training program in accordance with the NQF (National Qualification Framework) [15].

\section{Vocational Education in Indonesia}

In accordance with the Presidential Instruction of the Republic of Indonesia Number 9 Year 2016 on the Revitalization of Vocational Secondary Schools to Improve the Quality and Competitiveness of Indonesian Human Resources specifically addressed to the Minister of Education and Culture for; (a) developing a roadmap for SMK development, and (b) refining and synchronizing the SMK curriculum with competencies according to the needs of the linked and linked users to increase the relevance of 
vocational education that is not yet suited to the needs of the world of work [5].

One of the general policy of the Directorate of Vocational Development of 2015 is based on the Government of the Republic of Indonesia's municipality peroide 2015-2019 [6]. There are 3 (three) points of national education development programs, namely; 1) improving the quality of human life of Indonesia, 2) increasing people's productivity and competitiveness in international markets, and 3) revolutionizing the nation's character. The success of Vocational High School development is determined by networks built on all lines at both the central and regional levels and a proper understanding of Vocational School Development programs by various stakeholders [6].

\section{CONCLUSION}

The trend of the 21 st century is marked by the increasing complexity of technology and the emergence of a corporate restructuring movement that emphasizes the combination of technological and human qualities, causing the world of work to require people who can take initiative, think critically, creatively, and solve problems [13]. The humanmachine relationship is no longer a mechanistic connection but a communicative interaction that demands high-order thinking skills. Creativity skills are considered very important because new skills should be based on what the creators do as they improve personality attributes, cognitive abilities, talents, environmental factors, motivation, and knowledge of the field needed in developing one's creativity, and creativity enhancement is often a transformative process for individuals [2]. Furthermore, nowadays vocational education should develop critical, conceptual and creative thinking for; a) analyzing concepts and problems so that we can see more clearly, b) generating our own ideas to solve them, and c) presenting them consistently, coherently and persuasively.

According to Jean Piaget quoted by [1], education encompasses all values, not privileges one value above another. Education is every process with the individual's meaning of acquiring knowledge, developing attitudes and skills. Such processes are generally directed at three main objectives: 1) education for worker, 2) education of the citizen, and 3) education of human being. Based on the discussion and analysis of vocational education development in Asean, Germany, and South Korea, several efforts can be made to develop vocational education in Indonesia, among others;

1) An in-depth study is needed so that the interest of continuing study in vocational education is increased so that the interest in higher vocational education and input is better.

2) The implementation of the KKNI Curriculum (Indonesian National Qualification Framework) has been used by incorporating curriculum content using SKKNI (Indonesian National Work Competency Standards) which regulates vocational qualifications that define lifelong learning skills including learning skills and problem solving, interaction and cooperation, work ethics, aesthetics, communication and media competence, and others.'
3) Introduction of apprenticeship system is one of the good ways to develop vocational education and training. The apprenticeship or dual system can adapt the vocational education model in Germany.

4) The qualifications of vocational education teachers in Indonesia should be able to adapt the recruitment system of vocational education teachers in Germany, including appropriate university education degrees or appropriate polytechnics, having at least three years of work experience in fields relevant to their field and pedagogical mastering.

5) The internationalization of vocational education and training also aims to provide students with the necessary knowledge, skills and competencies in the international labor market and the multicultural community. Implementation requires experts who master the field of expertise and international standard. The development of education/learning in the field of technology (in college) as a form of technology disembodiment that refers to the demands of human resource characteristics that have a competitive advantage above, one of them is through the development of teaching industries [9].

6) To increase the number of SMK graduates the model of vocational education in South Korea that requires graduates to work in the business world / industry world for at least 3 years then can continue to college without having to take college entrance exams can be adapted.

7) To minimize the problem of 'mismatch skill' in vocational education, it is necessary to have a mechanism for linking school curriculum with the expected competencies of the business world / industry so that the type of work competence required for a particular job will be in accordance with the education followed.

8) The difficulty of organizing an internship program is due to the limited business and industrial world close to vocational high schools. Although there is already cooperation between the education department, the labor ministry, and the ministry of industry but this policy can not be immediately implemented.

\section{REFERENCES}

[1] Bambang Sugestiyad, Pendi-dikan Technopreneurship Berbasis Pada Kompetensi Global Dan Kearifan Lokal. Bogor: International Convention Center, Bogor, 18-19 Februari 2013.

[2] Jane Piirto.2011. Creativity for 21st Century Skills How to Embed Creativity into the Curriculum. Netherlands: Published by: Sense Publishers, P.O. Box 21858, 3001 AW Rotterdam, The Netherlands.

[3] Bryan Greetham. 2010. Thinking Skills for Professionals. New York: Palgrave Macmillan.

[4] Finch Curtis. R and Crunkilton. 1984. Curriculum Development in Voca-tional and Technical Education: Planning, Content, and Implemen-tation. Sidney. Allyn and Bacon Inc.

[5] Instruksi Presiden Republik Indonesia Nomor 9 Tahun 2016 Tentang Revitalisasi Sekolah Mene-ngah Kejuruan Dalam Rangka Peningkatan Kualitas Dan Daya Saing SDM Indonesia.

[6] Mendikbud. 2015. Rencana Strategis Kementerian Pendidikan dan Kebu-dayaan 2015-2019. Jakarta. Kementerian Pendidikan dan Kebudayaan.

[7] Ministry of Education and Science Technology (MEST). 2013. Vocational Education and Training in Korea: Achieving the 
Enhancement of National Competitiveness. Lee Ji-Yeon (KRIVET, Korea).

[8] Monika Aring. 2015. ASEAN Economic Community 2015: Enhancing competitiveness and employability through skill development. ILO Regional Office for Asia and the Pacific. Bangkok: ILO, 2015 (ILO Asia-Pacific working paper series, ISSN: 2227-4405 (web pdf))

[9] Mukhadis, Amat. 2009. Pengem-bangan Kemampuan Emulasi Melalui Teaching Industries Dalam Bidang Teknologi. Tekno-logi Dan Kejuruan, Vol. 32, No. 2, September 2009: 219-236.

[10] Slamet P.H. 2013. Pengembangan Pendidikan Kejuruan Model Untuk Masa Depan. Cakra-wala Pendidikan, Februari 2013, Th. XXXII, No. 1.

[11] Unesco. 2014. Education Policy Research Series Discussion Document No. 5. Education Systems in ASEAN+6 Countries: A Comparative Analysis of Selected Educational Issues. Bangkok: Published in 2014 by the United Nations Educational, Scientific and Cultural Organization.
[12] Ute Hippach-Schneider, Martina Krause, Christian Woll. 2007. Vocational education and training in Germany Short description. Luxembourg: Office for Official Publications of the European Communities.

[13] Pacific Policy Research Center. 2010. 21st Century Skills for Students and Teachers. Honolulu: Kamehameha Schools, Research \& Evaluation Division.

[14] National Economic and Development Authority. 2014. Philippine Development Plan 2011-2016 Midterm. Philippine: National Economic and Development Authority.

[15] EU Funded project managed. 2011. National Qualification Framework. Pristina: the European Commision Liaison Office.

[16] Undang-undang sistem pendidikan nasional sisdiknas no 20 tahun 2003.

[17] Peraturan pemerintah no. 29 tahun 1990 tentang pendidikan menengah.

[18] Viola Deutscher., Esther Winther. Instructional sensitivity in vocational education. Learning and Instruction. Volume 53, February 2018, Pages 21-33 